\title{
ARCHAEOLOGICAL EXPEDITION AS ESSENTIAL ASPECT OF SCIENCE AND EDUCATION IN THE SYSTEM OF HISTORICAL AND CULTURAL HERITAGE
}

\begin{abstract}
Any museum carries out three paramount functions: a competent preservation of historical heritage of mankind, studying and classification of collections of artifacts and its promoting. These three components of museum work are consistently interconnected and equal in their importance. We suggest to pay attention to such sphere of museum activity as organization and carrying out archaeological expeditions. Expeditions not only carry out their direct functions, which are detection and research of archaeological objects. They also become peculiar organizations capable to keep, revive and propagandize objects of a cultural heritage. Moreover, archaeological expeditions, creating the customs, traditions and behavior rituals, become peculiar examples of a certain subculture.
\end{abstract}

Keywords: archaeology, expedition, Nymphaion, excavations, Hermitage.

Archaeological objects shouldn't be isolated from a modern society and „assigned“ to scientific archaeological elite which would use them for especially scientific constructions the information about which practically isn't known to a wide range of people. This heritage shouldn't act in the immobilized kind, in passive forms of culture on inaccessible regiments of museum depots. It is necessary to study the archaeological heritage simultaneously within the limits of the several scientific disciplines considering archaeological objects in different aspects: archeology - as a source base for reconstruction of events of the past; museology - as an object of protection and presentation by museum means; monument studying - as a substantiated memory of the past; cultural science - as a cultural phenomena. Any museum carries out three paramount functions: a competent preservation of historical heritage of mankind, studying and classificating collections and its promoting. These three components of museum work are consistently interconnected and equal in their importance. In this aspect we suggest to pay attention to such sphere of museum activity as organization and carrying out archaeological expeditions.

Even from the structure of the Department of Classical Antiquities of the State Hermitage Museum (St. Petersburg, Russia) one can see that a special attention is paid to archaeology. The De- 


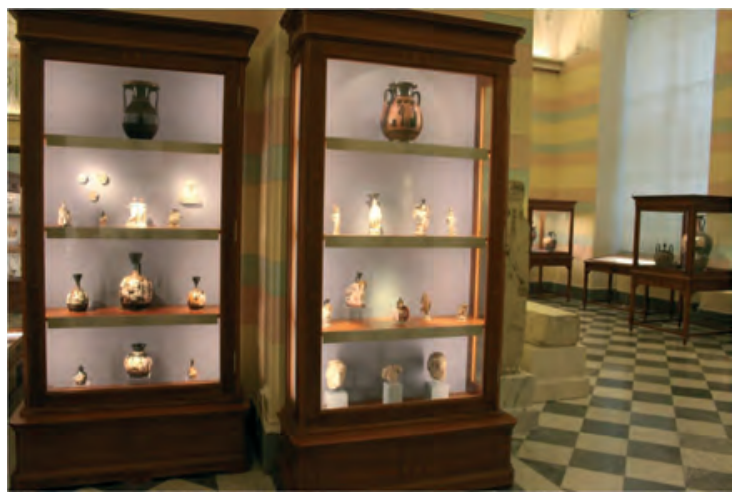

Fig. 1 Department of Classical Antiquities The State Hermitage Museum

partment is divided in two parts - the main part with the collections bought or presented and another one consisting of archaeological complexes and other subjects found exclusively in the course of systematic archeological excavations (Fig. 1). Strictly speaking all Departments pieces have once been found during excavation, at first casual or illegal, later - professional. And on the one whom found and transferred an item to a museum frequently depends, will it enter a circle of scientific interest of researchers or lay down on regiments dead cargo.

After Crimea joining Russia in 1784 the acquaintance with antique monuments which remained at coast of Black sea begun (Fig. 2). Thus on the cape Kara-Burun (on modern cards this cape is called Kamish-Burun) was found ancient city Nymphaion. The site of this ancient settlement occupies a plateau on the shore of Kerch strait (in the ancient time - Bosporus Cimmerian), to the west from which are located barrows and

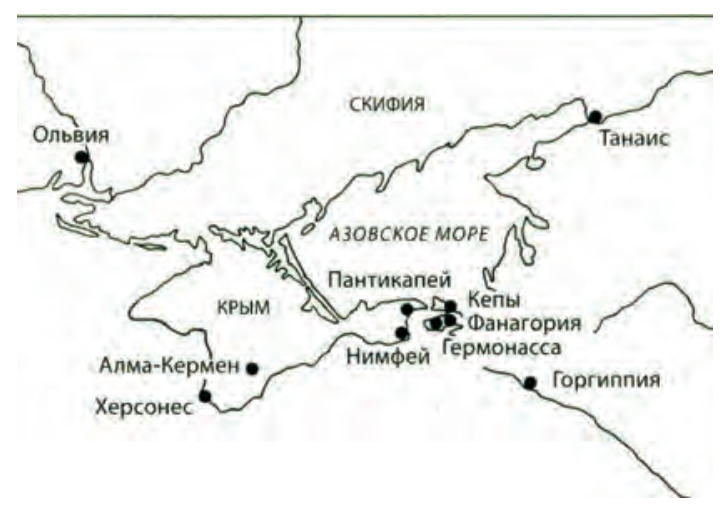

Fig. 2 The map of the Nothern Black Sea Area a soil necropolis. Nymphaion was based by colonists from Greece presumably in the first half of VI century B.C. (Fig. 3). Natives from island Samos probably took active part in the basis of this settlement which was named after the Greek word

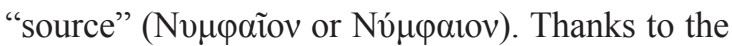
convenient arrangement near to harbor and to the fertile earths, Nymphaion soon became one of the leading centers of trade and the supplier of bread

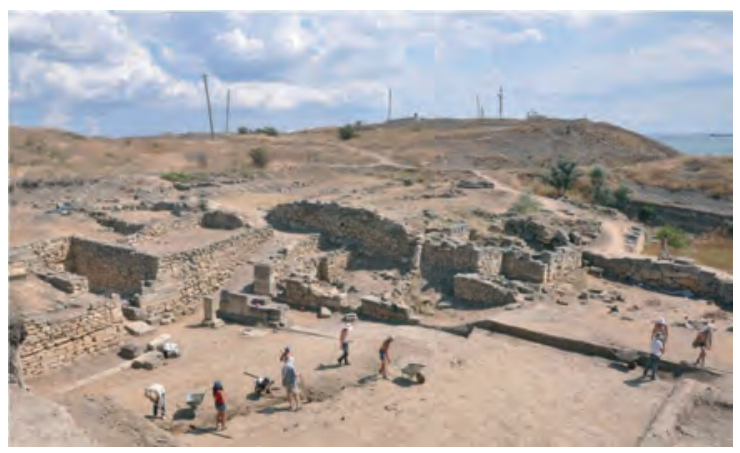

Fig. 3 View of the plateau on the cape Kamish-Burun and the Kertch strait

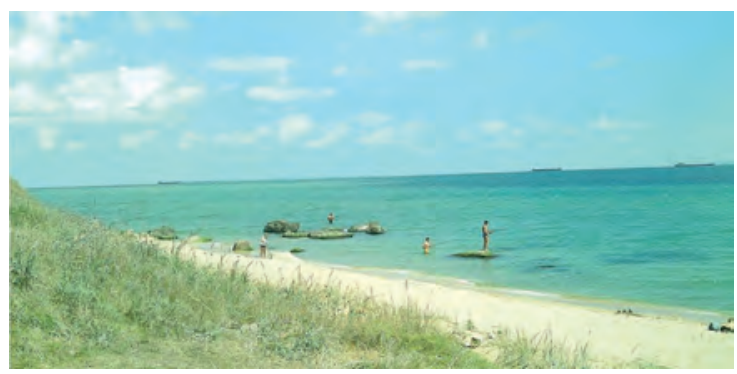

Fig. 4 Seashore of the Kerch strait

in the Bosporan state (Fig. 4). That's how ancient author Strabo described the city: "Panticapaeum is the metropolis of the Bosporians and is situated at the mouth of Lake Maeotis.The distance between Theodosia and Panticapaeum is about five hundred and thirty stadia; the district is everywhere productive of grain, and it contains villages, as well as a city called Nymphaion, which possesses a good harbour"(Strabo VII. 4).

The first regular archaeological researches of Nymphaion and its necropolis were made in 1876-1880 by the Imperial Archaeological Com- 


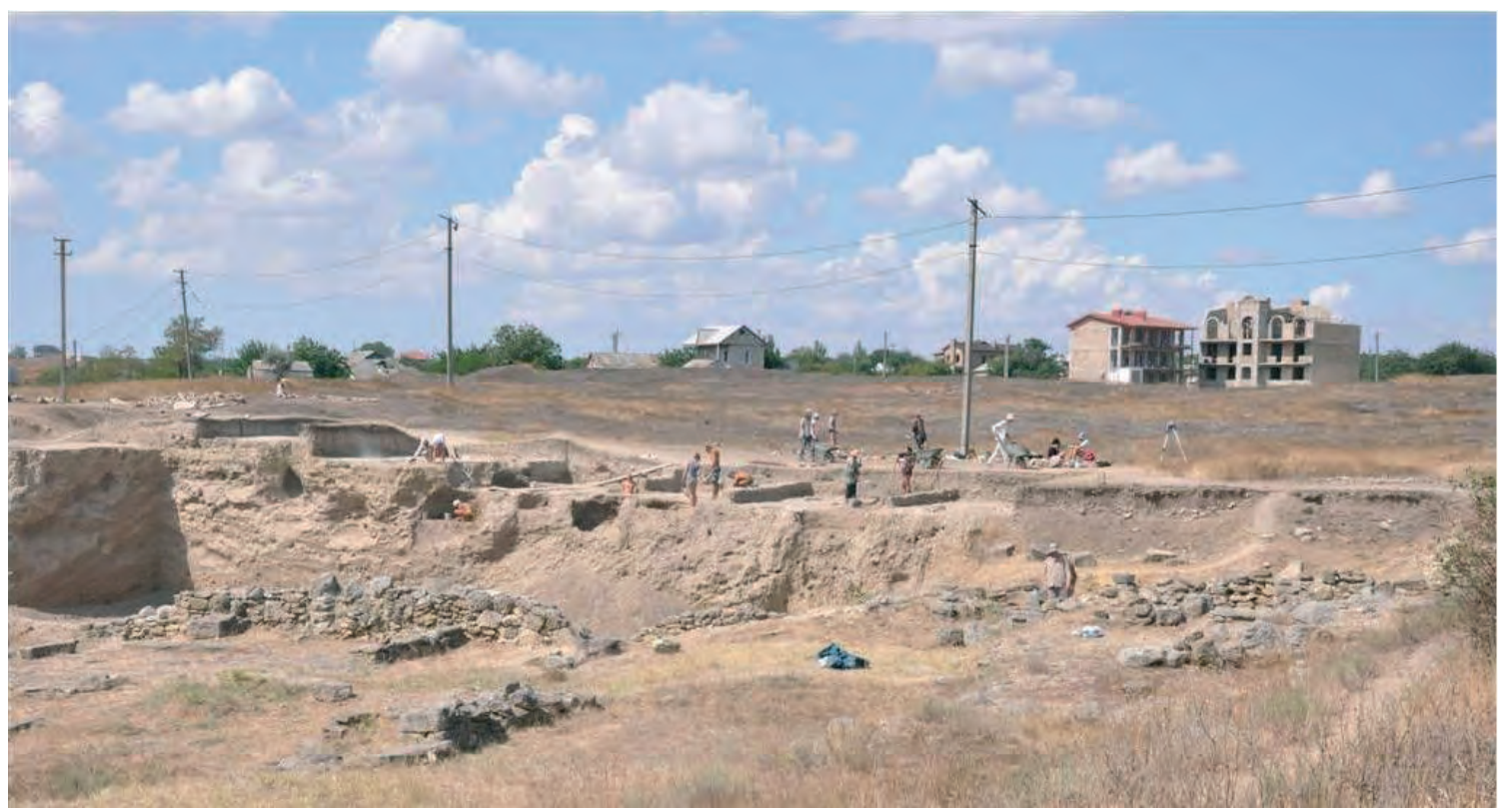

Fig. 5 View on the place of excavations

mission when the site of ancient settlement and barrows of Nymphaion have been described and put on the plan (OAK 1867, 1868, 1876-1880). Excavations proceed up to now. They stopped only twice, from 1914 to 1938 and from 1941 to 1945, both as a result of World wars. Nymphaion archaeological expedition of the State Hermitage Museum at the Crimea peninsula, now Ukraine, exists more than 70 years. During this time through it passed thousands of people. The monument causes a great interest in a wide range of people in Russia and abroad (Fig. 5).

In the expedition work specialists of the highest class, such as archaeologists, restorers, artists, architectures, photographers. They make site plan shooting, select found material and re-

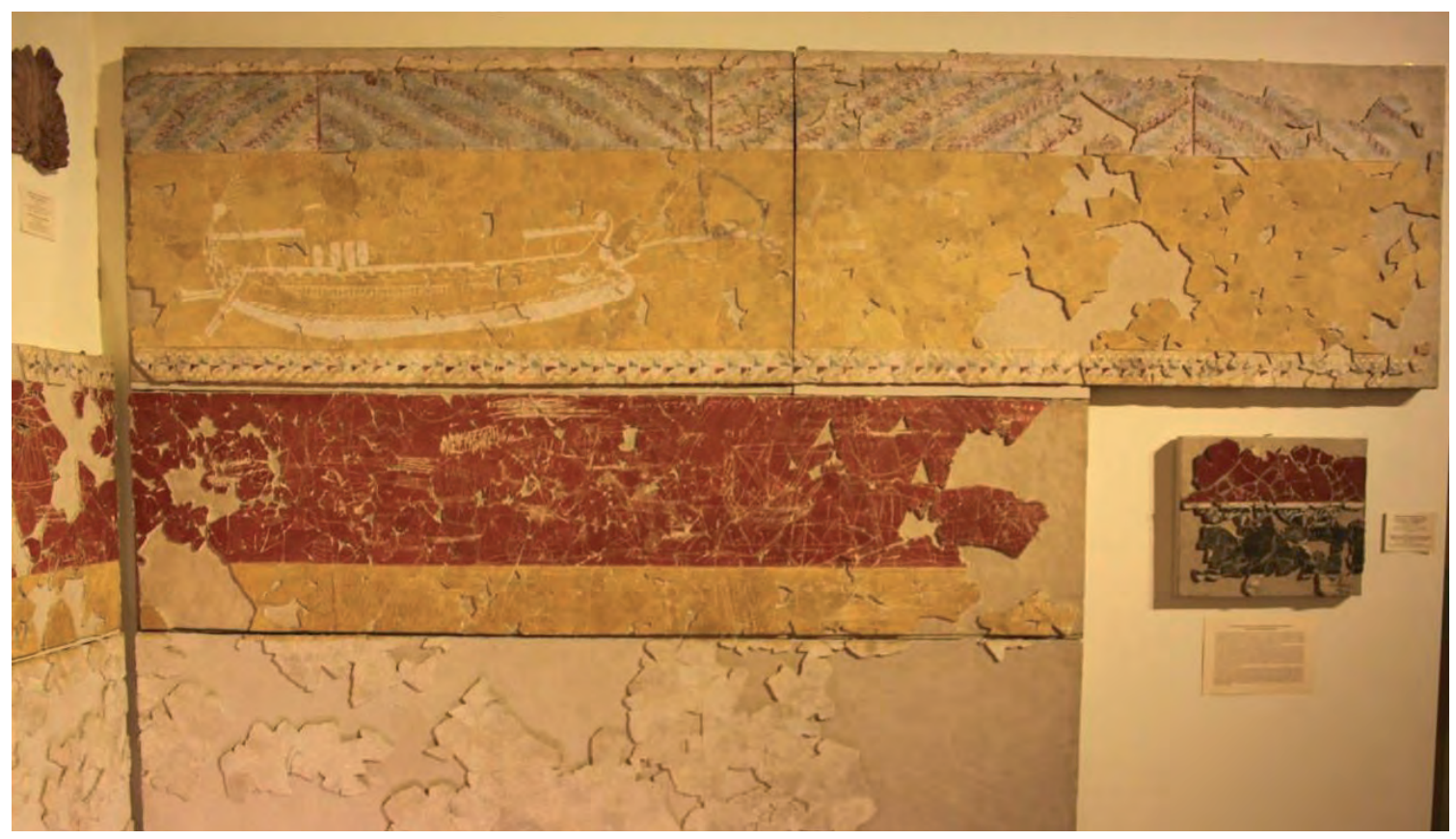

Fig. 6 Fresco with a ship from Nymphaion 


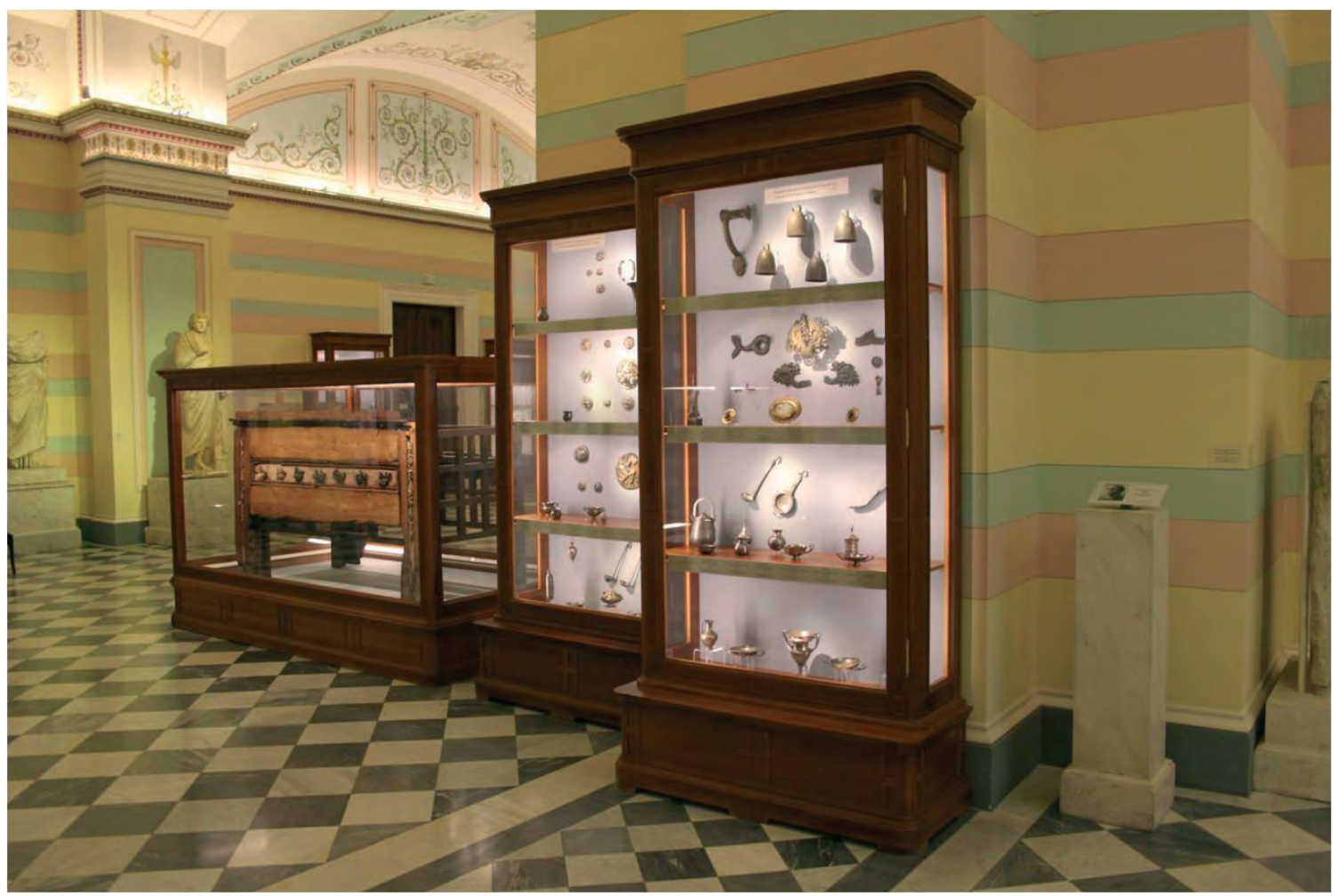

Fig. 7 New exhibition devoted to art and culture of the Bosporan Kingdom

store it. Then they fix the material; make drawings and photos before carrying them to the museum. Beginning from 90 ies of the $20^{\text {th }}$ century all founds are kept in Kerch.

Popularization of subjects found during excavations and cultural education through archeology is carried out in different ways. The results of excavations are regularly published as reports and scientific articles and sounded at annual archaeological conferences. International scientific conferences as for instance "Bosporan Phenomena" are periodically organized. And of course subjects once found in the expedition are exposed in St. Petersburg (the Hermitage Museum) and in Kerch (Fig. 6). Recently in halls of the Department of Classical Antiquities in the Hermitage was opened the new permanent exposition devoted to art and culture of the Bosporan Kingdom (Fig. 7). Also from time to time temporary exhibitions are made where items found in Nymphaion take part. Such exhibitions were held in Russia, Ukraine, USA,
Spain (Уильямс, Огден 1995; Древний город Нимфей 1999).

Also expedition bears educational function. Annually students of the St.Petersburg State University pass here their archaeological practice. Sometimes they are joined by the students from Belgorod and Niznij Novgorod Universities. Next year they often come back on a voluntary basis taking their friends with them. After the excavations students from the St.Petersburg State University come to the Hermitage on museum practice in order to study archaeological collections more thoroughly. Members of the archaeological circle from Dnepropetrovsk came in the year 2012 to try themselves in practical archaeology. Later most of them will work as specialists in museums, institutes, libraries. Besides, on the place of excavations excursions for different visitors such as experts, members of other expeditions, people having rest in Kerch and boarding houses are organized. Often here come buses with tourists from a neighbor's city Feodosiya. Since last year the 


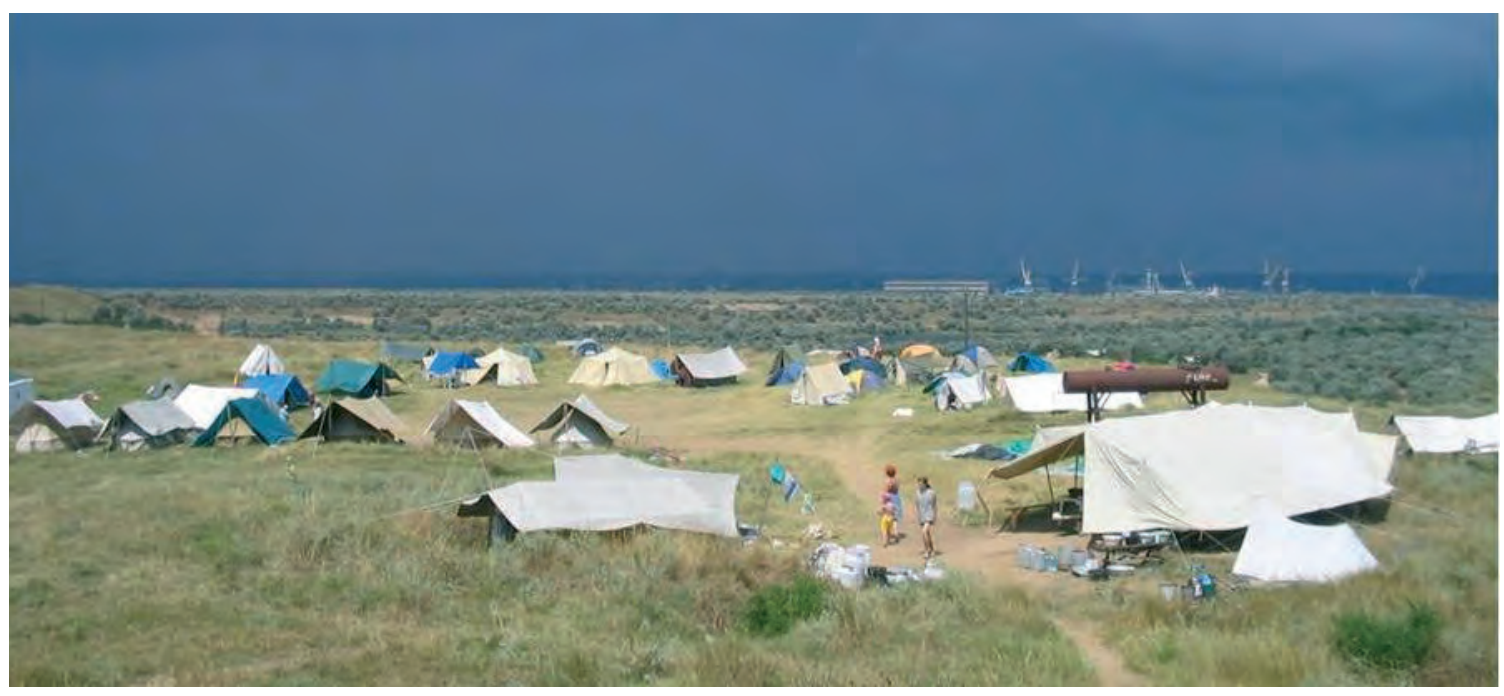

Fig. 8 Archaeological camp

Kerch museum arranged permanent excursions for all visitors of the ancient city.

Nowadays when new countries appear everywhere it is necessary to build relations anew not only between them but also between various organizations in these countries. In this situation organizing new complex international archaeological expeditions is a very good opportunity which can help to set friendly contacts both interstate and international. But of course not all passes so successfully as one can wish. Local inhabitants sometimes are not friendly. For example, sometimes in steppe round the camp there are fires which are very dangerous especially during the night when everybody sleep.

Besides it is impossible to dismiss constant activity of „black archeologists“. They undertake illegal excavation all year long. But especially attentively they look after the work of expedition so it is necessary to watch the place of excavations constantly. It is especially actual when excavations take place on a necropolis. At the moment the problem of safety of a site of ancient settlement during the interseasonal period should be solved because the place of excavations has neither fence, nor protection. As a result after the departure of the expedition acts of vandalism take place: boards are pulled down; holes dig out, walls broken. That's why it is necessary to expand educational work in order to increase a level of consciousness and culture of population.

And certainly for the decision of the problems mentioned above structure of participants of expedition is of a great importance. Long years it represents a solid collective of adherents where there is an absolute equality irrespective of age and the social status of its members. Each season approximately 100 persons passes through expedition The main kernel of constant participants of the expedition is approximately $60 \%$ from total number.

Life of the expedition has its customs and traditions developed for last decades. The tent camp is located in steppe on the territory of a site of ancient settlement (Fig. 8). Because of the absence of water it is brought in tanks. Products are brought from a city; the garbage is taken out by special cars. We rigidly watch an ecological condition around. After the camp removal all traces of residing are destroyed.

This way of life, almost torn off from civilization,develops special human relations when life of everyone proceeds in close dialogue with all members of collective. It inevitably demands creation of a stable psychological climate of collective of adherents that can be reached by different ways. For example, certain selection of the future participants of expedition is absolutely necessary 
because it is frequently found out that not all of them understand what exactly they will do. Some people assume this voyage as a certain way of pleasant rest on a seacoast.

Unlike fashionable now role-playing games an expedition don't recoup role game but create some kind of role techniques. Various competitions are regularly held here. As long as all member of expedition, except „the higher command structure“, cook by turn we regularly organize competitions on the best preparation of a dinner or on the most original dish. Dances and discos are often arranged. Birthdays and, of course, the City Day are marked. It is a separate holiday when on the improvised platform in the camp center the dramatized representation is arranged. On a seacoast in the evenings are arranged fair-shows, singing and playing guitars around a fire. Several collections of songs written in the expedition were already published. Sometimes we spend evenings of memories where new participants of expedition can learn a lot about stories and tradition of the Nymphaion expedition. Children who come with parents aren't forgotten also and take a certain part in camp life. Competitions of children's drawings with rewarding of winners in different nominations are arranged.

As a result the social stratum of people who passed the archaeological school and is now capable, together with real experts, to teach newcomers skills and working methods of excavations and ceramics sorting is created. Whence they arrive all of them consider Nymphaion expedition as their second homeabout which they care. Annually here come to work representatives of many countries, such as Germany, Poland, USA, New Zealand, Belgium. So it is not surprising that people try to register in advance for the next season as long as the list of participants is limited. And they are very much upset, when for whatever reasons they don't manage to arrive.

\section{BIBLIOGRAPHY}

\section{Strabo}

Strabo: The Geography,[e-book], Loeb Classical Library, 8 volumes, Greek texts with facing English translation by H. L. Jones: Harvard University Press, 1917 thru 1932. Available throughBill Thayerhttp://penelope.uchicago.edu/Thayer/E/ Roman/Texts/Strabo/home.html 27 February 2013].

\section{ОАК 1867, 1868, 1876-1880}

Отчет Императорской археологической комиссии, Санкт-Петербург: Типография Императорской Академии наук.

Уильямс Д., Огден Дж. 1995

Греческое золото. Ювелирное искусство классической эnохи V-IV века до н. э. Каталог выставки, Санкт-Петербург: Славия.

\section{Древний город Нимфей 1999}

Древний город Нимфей. Каталог выставки, Санкт-Петербург: Издательство Государственного Эрмитажа.

\section{REZIME}

\section{ARHEOLOŠKA ISKOPAVANJA KAO NAJVAŽNIJI ASPEKT NAUKE I OBRAZOVANJA U SISTEMU ISTORIJSKOG I KULTURNOG NASLEĐA}

Ključne reči: arheologija, iskopavanja, Nimfej, Ermitaž.

Svaki muzej ima tri najvažnije funkcije: kompetentno čuvanje svetske istorijske baštine, proučavanje i klasifikaciju zbirki nalaza i njihovo popularizovanje. Ove tri komponente muzejskog rada se međusobno prožimaju i podjednako su važne. U ovom radu je pažnja posvećena onoj sfe- 
ri muzejske aktivnosti u okviru koje se organizuju i sprovode arheološka iskopavanja. Iskopavanja pored otkrivanja arheoloških objekata, postaju specifičan metod koji je u mogućnosti da sačuva, oživi i popularizuje predmete kulturnog nasleđa. Štaviše, arheološka iskopavanja kroz formiranje običaja, tradicije i rituala, postaju specifični primeri određene sub-kulture.

Sve ovo možemo pratiti na lokalitetu Nimfej (Nymphaion)na Krimu u Ukrajini, na kome istraživanja sprovodi Državni Muzej Ermitaža već više od 70 godina. Tokom ovog perioda, kroz njega je prošlo na hiljade ljudi. Osim stručnjaka, kao što su arheolozi, restauratori, umetnici, fotografi, ovde kao volonteri rade studenti i predstavnici raznih zemalja. Predmeti otkriveni tokom iskopavanja se izlažu u muzeju Ermitaž i u gradu Kerču. Takođe se organizuju povremene izložbe na kojima se mogu videti predmeti otkriveni u Nimfeju. Ovaj lokalitet pobuđuje interesovanje velikog broja ljudi kako u Rusiji tako i u inostranstvu. Učesnici iskopavanja održavaju redovne sastanke u Ermitažu, dok studenti dolaze da proučavaju arheološke zbirke. Primer arheološkog iskopavanja Nimfeja pokazuje da slične organizacije bez sumnje podižu svest javnosti o očuvanju i daljem razvoju interesovanja za svetsku kulturnu baštinu. 